\title{
The prophetic voice of the ecumenical church in South Africa and the role of the Volkskerk van Afrika
}

\author{
Katts, Donald \\ Stellenbosch University \\ djkatts@mweb.co.za
}

\begin{abstract}
In this essay the author briefly wants to state the historical events that led to the spirit of Ecumenism. Secondly the article wish to give an overview of the early history of the Volkskerk van Afrika and state the church's experience and response at the time. Thirdly the article outlines how the Volkskerk van Afrika came to join the ecumenical movement and finally portrays what the prophetic voice of the ecumenical Church in South Africa entails or should be today.
\end{abstract}

Keywords

Ecumenical, Volkskerk van Afrika, Prophetic voice, Ecumenism, Ecumenical Church

\section{Introduction}

Though this paper deals with the prophetic voice of the ecumenical church and the role of the Volkskerk van Afrika the author considers it also an opportunity to introduce the reader to the church known as the Volkskerk van Afrika. This Church was brave enough to chart its own course in proclaiming the gospel of salvation, liberation and dignity. It was and still is a church that shows faith in ecumenism and is still trying to discern the voice of God in the ecumenical movement and in our own ranks.

\section{In search of a plan to work together as churches}

In 1860 the Dutch Reformed Church (DRC) held a big mission conference in Worcester in the Western Cape, attended by delegates from the Lutherans, 
Moravians, Episcopals, Independents and Presbyterians (Gerdener 1952:32-72).

A further conference was held to embrace the rest of the country and eventually these efforts led to the establishment of the General Missionary Conference of South Africa (GMCSA) in 1904. The purpose was to negotiate wider interaction between the churches as well as looking after the interest of the "Naturelle" (indigenous people of SA).

The (GMCSA) had eight similar conferences before it ceased to exist in 1936. In its place came the Christian Council of South Africa (CCSA), which later changed its name, and in 1986, became the South African Council of Churches (SACC).

From the reasons for greater cohesion and ecumenical witness, it is obvious that they had in mind, and planned accordingly, to address the socioeconomic and political issues that have affected the lives of people in South Africa.

\section{Ecumenism}

The terms "ecumenical" or "ecumenism", derived from the Greek word oikoumene, and refers to or supports specifically the meaning of "the whole inhabited earth". Thus the World Council of Churches (WCC) interprets its work as "everything that relates to the whole task of the whole church to bring the gospel to the whole world".

Generally speaking "ecumenical" or "ecumenism" portrays the picture of working together, of being joined over all kinds of borders in their pursuit to bring about justice, human dignity, equality, freedom and human rights.

\section{The origins and early history of the Volkskerk van Afrika}

Ecumenism, even if it is interpreted in its narrowest sense as "working together across boundaries and borders", took the particular form of paternalism in the Republic of South Africa at the turn of the twentieth century, owing to the rapidly changing socio-economic and political landscape. 
Dirkie J Smit notes the separatist nature of Christian churches during this period, with the emergence of the Zionist and Ethiopian churches among African Christians, the steady movement towards an "ideology of apartheid" in the Afrikaner Reformed churches and the colonialist orientation of churches that had been founded on a missionary basis (Smit:14-15).

About the last-mentioned churches Smit remarks that:

"They supported the British cause in the Anglo-Boer War ... They had white leadership and generally supported the racially discriminatory constitution of the Union of South Africa in 1910 ...” (2007:15)

The Volkskerk van Afrika (VVA) was established as an independent Reformed denomination in 1922, starting with two founding congregations in District Six, Cape Town, and Die Vlakte in Stellenbosch respectively. At the inaugural service of the VVA in the City Hall, Cape Town on the $14^{\text {th }}$ of May 1922, 1500 persons attended the afternoon service. As a newly established denomination, the Volkskerk drew people from the Wesleyan and Congregational Church. With the establishment of the Stellenbosch congregation, people of the Anglican, Wesleyan and Rhenish Church joined the Volkskerk (Eerste Verjaardag Jaarboek [First Anniversay Year Book], 1923:8). With the establishment of the Volkskerk in Genadendal on the 27 January 1924, about 286 persons became members, apparently from the Moravian Church mainly, as this was a Moravian Mission Station (Derde Verjaardag Jaarboek [Third Anniversy Year Book], 1925:14).

Both congregations, located in District Six and Die Vlakte in Stellenbosch, were located in the heart of the coloured communities of the time, and started out as independent breakaway movements.

What was critically important in the founding of this newly independent church movement was that many of the early leaders from both founding congregations were born in the second half of the nineteenth century (Janari in 1869, Forbes in 1876), and experienced the segregationist policies of the colonial government, and its resonance within the church itself.

Their vision was formed by the critical events that laid the foundation for what was to transpire in the first half of the twentieth century, leading up to 
the consolidation of Afrikaner nationalism of the 1930's and the eventual take-over of political power in 1948.

Denominations were becoming increasingly separated along colour lines, but the leadership of those denominations and congregations that were not white was still retained by white office bearers.

It was this paternalistic control that caused a rift between the founding minister of the Volkskerk, the Rev Joseph Forbes, and, firstly, the Methodist Church from which he resigned (The Methodist Churchman, 1920:5) and, subsequently, the Harrington Street Congregational Church in March 1922 (Volkskerk van Afrika, Silver Jubilee Celebrations edition of the Year Book, 1947:9).

These sentiments were echoed by congregants from various church denominations in Stellenbosch who were already in contact with Rev Forbes concerning the formation of "... their own church ..." in a spirit of "self-help ..." (Ibid, 10).

The establishment as an independent church would bring about substantial economic sacrifice and social stigmatisation, such as being labelled a "Volkieskerk". This was a derogatory reference to the status of the coloured community of the time as being less affluent, more economically dependent on white employers, and being of so-called " mixed blood" - genetically inferior.

This was the social context already polarising the communities in haves and have-nots, broadly speaking.

This raises the question as to why people would break away from the acceptance by and security of the well-established mission churches of the time.

John Ngubani, in his contribution, Theological Roots of the Independent Churches reflects that:

Obviously, before breaking away from the existing church establishments, or founding new churches, the leaders of such moves must have done a lot of theologising. As men and women of Christian faith I presume, these leaders reflected on and examined their ordinary human experiences as Christians in their respective Christian 
communities and in their 'world' in the light of the contents of their Christian faith. Evidently, the result of this reflection and examination led them to act as they did" (1968:73).

Fundamentally such an action constitutes reading the Word (the Bible) and reading the world.

It is essentially a contestation - an inner struggle as well as an oppositional stance in public - about the biblical message and the guidance it provides for human existence. It was also a struggle for the church as one of the main vehicles for propagating and interpreting this message.

It is a search for "truth" as revealed by Scripture, and for a way of reformulating that truth in the light of contemporary experience.

\subsection{The experience}

Starting at about the middle of the nineteenth century at around the time that the British settlers arrived, the British government changed its stance towards South Africa. From regarding it as merely a halfway staging station to its rich Eastern colonies, the imperial government became interested in the whole of South Africa as a future asset to its empire. This resolve was strengthened when diamonds and gold were discovered from 1867 onwards. But this fundamentally changed the manner in which the role of the indigenous population was perceived.

The fairly liberal policies of the past were revised and in November 1899 in a letter Alfred Milner wrote:

"The ultimate end (for South Africa) is a self-governing white community, supported by a well-treated and justly-governed black labour from Cape Town to Zambezi” (1988:141).

He regarded the Anglo-Boer War as "a White family quarrel” (Ibid, 141), and carefully avoided using black troops as far as possible, so as to exclude the black community from being part of any future negotiations on the future of the country.

Segregation as a concept was first aired in a 1905 report of the South African Native Commission, again under Milner's leadership, and it became the 
blueprint for racial discrimination, and spatial separation that later, in intensified form, constituted apartheid.

The National Convention that drafted the concept constitution of the Union of South Africa was all white and resolved unanimously "only persons of European descent shall be eligible as members of either House of Parliament" (Ibid, 144).

This was done notwithstanding numerous previous promises to the contrary and despite all the deputations and protests from the broad black community.

For many this was the writing on the wall. In 1923 the founder and first pastor of the Volkskerk, the Rev Joseph John Henry Forbes (a former ordained minister of the Methodist Church of Southern Africa), in an address to the people assembled at the laying of the cornerstone of the Volkskerk school hall in Stellenbosch summarised his perceptions of the historical context within which the church was established as follows:

"Die geest van selfbewussyn onder die kleurling was gebore in 1910, wanneer Parlement, by 'n akte die kleurlijns skerp trek en 'n perk stel tussen blank an gekleurd, teen die gemoed van die gekleurde man. Toe kom die broeisel duidelik voort die hele party jare aan die broei was.

Van af die tyd, kan jy duidelik sien verskil in die kerke, waar die gekleurde moet agter sit of weggewys word. Verskil in die skool deur aparte geboue. Laer onderwijs vir ons gekleurde kinders, en laer salaris vir ons onderwysers. Verskil in die nywerheid, sodat in die industrieele wêreld die bruin man en grootendeels deur sij kleur vir minder prys sij werk en sweet moet verkoop, en verkil in die politiek om dat in Afrika, lede van die volksraad en senaat net Europeanen moet wees" (Excerpt from Hoeksteen Leggen Aansprak, Seremonie van Skoolsaal Hoeksteen, Volkskerk van Afrika, Stellenbosch, 29 Desember 1923, 3). 
They would have been aware of the manner in which resistance and protest movements such as the Bhambata Rebellion ${ }^{1}$ (1906), the non-violent protests staged by Mahatma Ghandi were crushed, and even the armed miners' strikes were ruthlessly dealt with by the government.

They would have seen the dissention and in fighting in the Industrial and Commercial Workers' Union of Clements Kadale and the African People's Organisation of Dr Abdurahman, and the stance of the ANC as representative mainly of black political aspirations.

They would have been aware and had at least some belief in the general sentiment in the coloured community that there was goodwill in the liberal white community of the Cape towards helping the advance of coloured aspirations.

This is borne out by the numerous references to donations of land and patronage to the Volkskerk in the early yearbooks. As examples, mention can be made of the continued presence of advocate Alexander $\mathrm{KC}$ at functions of the church, a donation of an acre of land in the Kensington Reserve (currently Windermere) by the Christian Marais Trust (Tweede Verjaardag Jaarboek [Second Anniversary Year Book], 1925), ten plots of land in Diep River by Mr George Brownhill (Derde Verjaardag Jaarboek [Third Anniversary Year Book], 1925:4), fifty morgen of land and a homestead for the purpose of establishing an orphanage ${ }^{2}$ at Jonkersdam by Mr FB Steer in 1928 (Volkskerk van Afrika Silver Jubilee Celebrations, 17).

Meanwhile socio-economic conditions on the Cape Flats and in black townships had worsened as a result of the general economic depression. It was also a period in which increasing attention was being given to the

1 The Bhambata Rebellion took place in the Mpanza Valley, Kwazulu-Natal. This happened after the British government decided on a poll tax of 1 pound of sterling for every black inhabitant from 1906. The South African government called the military in and between 3000 and 4000 people were killed.

2 Volkskerk Weeshuis. The land (6 plots) and a homestead at Jonkersdam was a bequest from Mr FB Steer to be used for charitable work. An orphanage for delinquent boys was started in 1928, closely supervised by Mrs "Juffrou" Rosina Forbes, the first wife of the Rev JJH Forbes. At the time of her death in 1937 the original number of inmates had grown from nine to forty. The orphanage was inter-denominational, as none of the boys were connected to the Volkskerk (Year Book, 1937:12; Silver Jubilee Celebrations Year Book, 1947:17, 64-65). 
so-called "poor white question". According to the Carnegie Commission (1937) that conducted an intensive study of poverty in the white community the white Dutch Reformed Church began to highlight this phenomenon as early as the middle 1890's and campaigned vigorously for greater assistance for that sector of the population.

The mainstream Afrikaner churches, in particular, did not target poverty as a national socio-economic condition but rather as a racially focused issue.

Dirkie Smit, in his article "Reformed faith, justice and the struggle against apartheid" (2007) provides a succinct overview of how official apartheid came to be legitimated by an ideology and even by what he calls a "theology of apartheid". What emerges is a history of increasing separation along racial lines within the mainstream, particularly Afrikaans churches (2009:28-29).

\subsection{The response}

Following the reasoning of Ngubani, as given earlier, we can now examine what the response of the founder members of the Volkskerk was.

In 1921, as a prelude to the founding of the church as an independent body, a pamphlet was issued by the Stellenbosch contingent of what was to become the Volkskerk.

The aims of the movement were described as being:

- How to improve the position of our people spiritually as well as temporally, that it may be of benefit to our generation, and to the generations to come.

- How to make better provision for our aged and sick, which are no longer in a position to provide for themselves.

- To help our people, who are in distress, over circumstances they had no control, and to foster a more united feeling of relationship among our people, in both spiritual as well as temporal matters."

The pamphlet, intended for “... our coloured people in general ..." expressed explicitly that 
“... there must first of all be 'Spiritual Unity' among our people to bring about closer relationship, and that it will only follow when our people worship God under one denomination..." (Okkers, D United National Church of South Africa).

The "volkskerk" idea was not a new one in South Africa, and there was no perceived contradiction between a separatist church along ethnic lines and the church of God as one denomination.

The "church of God" was perceived, as the church of the persecuted, the marginalised and the outcast, and Forbes also makes this connection in the same sermon at the laying of the cornerstone referred to earlier.

He says

“... Die verdrukking was bitter en droevig, maar gelijk in die dae van Israel in Egipte, in ook die dae van die eerste Kristenen, wanneer die verdrukking lijdsaam wert en die lijdsaamheid bevinding en die bevinding hoop, en die hoop in Kristus beskaam nie. Net so vandag met die gekleurde ras van ons land."

This was the vision that informed the founding of the Volkskerk van Afrika, and which found resonance in many communities, leading to an astonishing growth of congregations, churches and church schools during the 1920's and 1930's.

At this historical juncture two of the founding principles of the Volkskerk, apart from its biblical orientation, were "self-help" and "side by side" with other churches, particularly with those white church denominations with which the Volkskerk had historical bonds. (Forbes. Words of welcome in Year Book Tweede Verjaardag, 1924:9-10.)

This was also the vision that came to challenge the church in later years and raised the question of exclusion and therefore, a sin, similar to which the white churches were accused of.

Talks in the late 1960's and early 70's with the United Congregational Church of Southern Africa led us to sending our theological students to Adams United College in Pietermaritzburg where they studied with students from the Methodist, Anglican and Presbyterian churches, thus making it an ecumenical environment. 
In 1978 under the leadership of Rev Lesley Crotz and Rev Simon Adams, membership of the South African Council of Churches (SACC) was put up for discussion, but because of the World Council of Churches' (WCC) supposed support of "terrorism", it was rejected by an inward looking and largely conservative church leadership. This charge of "terrorism" was levelled against the WCC by the then National Party government as part of the propaganda campaign against anybody or institution that supported the anti-apartheid struggle.

These two younger members of the highest governing body of the Volkskerk, Crotz and Adams, were deeply involved in the anti-apartheid struggle on the basis of their interpretation of the gospel, and the ensuing debate inside the church between the traditionalists and those who made a different connection between spirituality and politics would be determining in the future direction of the church.

Ten years later, at the same venue, the issue of joining the South African Council of Churches ${ }^{3}$ was tabled again and the Synod decided to become members in $1988 .{ }^{4}$ This decision gave way to us becoming members of other ecumenical bodies like the Southern Alliance of Reformed Churches, World Alliances of Reformed Churches and in 2010 we joined the World Communion of Reformed Churches.

With the establishment of Ecclesia at the University of Stellenbosch, we were partakers in the ecumenical initiative and co-published Word and Worship, a South African lectionary, also used in our congregations.

Our contribution to ecumenism can be seen in the fact that we supported the idea of co-operation, cohesion and unity among Christian churches. By our becoming part of the ecumenical movement, we brought the voice of the marginalised to the centre of discussion, something that was and is still often overseen or neglected. In joining the ecumenical church, we willingly and consciously acted as agents of the ecumenical body by campaigning for the spirit of ecumenism. Many local ministers' fraternals were established and or joined. I see our presence as serving to remind the ecumenical body

3 In 2011 The SACC issued a document called - A call to prayer for Christian discernment and choice: Local government elections. 18 May, 2011

4 See Volkskerk van Afrika, Synod Workbook, 1988 
that it is only in reading the scripture together and listening together to the voice of God that we learn and discover the truth of the gospel as well as coming to understand the will of God for our time.

\section{The prophetic voice of the ecumenical church in South Africa today}

From an under-privileged and socially, politically and, to an extent, spiritually marginalised perspective, the ecumenical church was very strong, active and committed prior 1994, to critically and vitally champion the cause of justice, freedom, democracy and non-racism. It was even referred to as the struggle church, the voice of the people, the church of God.

The South African Council of Churches (SACC) Parliamentary Office, ${ }^{5}$ consultations with the government, inter-denominational ministers' fraternals, bible study groups, membership of the World Council of Churches (WCC), World Alliance of Reformed Churches (WARC), Africa Alliance of Reformed Churches (AARC) and the World Communion of Reformed Churches (WCRC), are the different well-known faces of ecumenism, and as the Volkskerk, we were and still is a member ${ }^{6}$ of these ecumenical bodies.

Dirkie Smit alludes to the fact that the impact on the church was much greater than the impact of the church - referring to the "impact of the rapid and radical processes of transformation into a democratic, pluralist modern society, deeply affected by the present worldwide collapse into cultural, economic and political globalisation" (2007:72).

5 The South African Council of Churches Parliamentary Office produced a document on practising faith in the public arena: Advocacy and Public Policy as a means to inform and educate South Africans who are eager to live out the rights and responsibility of our constitution. Marshalltown. 2006. They also produced the document called, Religions, the Promotions of Positive Discipline and the Abolition of corporal Punishment. A position paper. Cape Town: Salty Print. 2007.

6 Rev Lesley Crotz served as chairperson of the Southern Cape Council of Churches, a branch of the SACC and was then executive member of the SACC (Golden Jubilee Brochure, Volkskerk van Afrika, Mosselbaai, 1992:40). The descision to stay, members of the SACC and in future to strengthen our relationship was condone on our 2004 synod. (Volkskerk van Afrika - Synod workbook, 2005:23). 
Still the ecumenical church does have a transformative and critical role to play in our society, though different, less polarised, diverse and multi-cultural and religious. Our societies are still plagued by violence, corruption, crime, abuse, racism and discrimination, economic inequality, poverty $^{7}$ and even gangsterism to name a few of the ills that demean our collective humanity.

The ecumenical voice should be heard where people suffer because of unjust labour practices. Over the past three months (Desember 2012, January and February 2013), farm workers (especially in the Western Cape), protested against the minimum day wage of R69. Involvement of the ecumenical church in the negotiation processes is of utmost importance, as is its presence at grassroots level. An affordable, life-giving and dignified wage contributes immensely to a person's human dignity, self-esteem, sense of self-worth and a stable family life.

The prophetic voice of the Ecumenical church should be heard on issues affecting the quality of our children's education, starting with the overcrowded classrooms to the pass percentage of only $30 \%$ in some instances. It should be declared unacceptable and a sin against humanity and an affront to the dignity of children.

A challenge for the ecumenical voice of the church is in the area of gender, with special focus on the role and education of men so as to portray the kind of role model as a faithful and respectful husband, loving and caring father of integrity in the family, and as a hardworking, serving and helpful community member as well as a reliable and respected citizen.

One, if not the biggest, challenge for the ecumenical church in current South Africa, is the economic divide between rich and poor, the super rich and the super poor. Others refer to it as economic oppression. The government launched a National Development Plan in 2011 with the aim, "to attack the plight of poverty and exclusion, and promote economic growth at the same time, creating a virtuous cycle of expanding opportunities, building capacities, reducing poverty, involving communities in their own development, all leading to rising living standards" (Terreblanche 2012:116).

7 See Sarah Mosoetsa's Eating from One Pot (2011) to get an comprehensive idea of poverty in South Africa. 
To show the vastness of this problem, Terreblanche asks: "Why has the commission not concentrated on the unequal power relations, the unequal property relations and the unequal opportunities that are making the new South A frica society a very unjust society - just as similar inequalities made apartheid South Africa a very unjust place in which to live? (2012:118). Sarah Mosoetsa argues and conclude in her book, Eating out of one pot, that the ANC government's social policies have failed to alleviate poverty in South Africa, which makes the role of the ecumenical church much more critical and urgent. The ecumenical church should help in finding necessary policies for implementation so as to address the poverty, unemployment and inequality problem of our South African society.

The mode in which the ecumenical church can serve society and thus address the above and other challenges is through the offices of Christ, namely that of prophet, ${ }^{8}$ priest and royal servant. As prophet the ecumenical church could help society to envision a picture of a new society, driven by justice, dignity and human rights. As priest the ecumenical church can inspire everybody to overcome alienation, work for social solidarity and become hospitable. As royal-servant, the ecumenical church can foster the idea that, in the words of Nico Koopman, "my neighbour is, negatively put, the limit of my freedom, and, positively put, a personal call to service" (Koopman 2012).

Besides the many other challenges, ${ }^{9}$ the ecumenical body should rediscover the power of ecumenism and thus should be able to find the ecumenical language to inspire people to engage as such to be transformative and infuse hope for the good life.

\section{Conclusion}

I have tried firstly to show the meaning of ecumenism and secondly to outline the historical development of the Volkskerk van Afrika. Thirdly I tried to portray the role I think the ecumenical church in our current multi-

8 See Nico Koopman's article, Public Theology and the public role of churches in South Africa today? Some insights from the confession of the threefold office of Christ, for the other modes of prophetic speaking, like criticism, story-telling, technical analysis and policy discourse, the church can take up.

9 See Wolfgang Huber (1993), for other challenges faced by the ecumenical movement. 
cultural, diverse and socially and economic unequal society should play. I am of the opinion that the ecumenical church in fulfilling her prophetic role, can contribute to a humane, dignified and just South Africa where all are economically equal and socially free.

\section{Bibliography}

Adonis, J 2013. Sending en Ekumene in die Familie van die Nederduitse Gereformeerde kerke in Suid Afrika. [Online] Available:

http://Sun025.Sun.ac.za/portal/page/portal/Arts/Departement1./geskenidenis. [25 February 2013].

Gerdener, GBA 1958. Recent Developments in the South African Mission field. Kaapstad: NG Kerk-Uitgewers.

Huber, W 1993. Perspectives for ecumenism in the nineties (371-378). In The Ecumenical Movement Tomorrow. Suggestions for Appraoches and Alternatives, Marc reuver, Friedhelm Solms, Gerrit Huizer (editors). Kampen: KOK Publishing House.

Koopman, NN 2012. Public Theology and the public role of churches in South Africa today? Some insights from the confession of the threefold office of Christ. (Unpublished. Stellenbosch University).

Mnuguni, 1988. Three Hundred Years, Unity Movement History Series. APDUSA Cumberwood. First published in 1952 by the New Era Fellowship.

Mosala, IJ and Tihagale, B (Editors) 1986. The unquestionable right to be free. Essays in black theology. Braamfontein: Skotaville Publishers.

Okkers, D 1921. United National Church of South Africa. Pamphlet issued by the UNCSA, Stellenbosch.

Smit, D 2007. Essays in public theology. Collected essays 1. Stellenbosch: Sun Press.

Terreblanche, S 2012. Lost in Transformation. South Africa's search for a new future since 1986. Johannesburg: KMM Review Publishing Company. 